\title{
Meta-analysis of the correlation between vitamin D and lung cancer risk and outcomes
}

\author{
Jian Liu ${ }^{1, *}$, Yongquan Dong ${ }^{1, *}$, Chao Lu ${ }^{2}$, Yina Wang ${ }^{1}$, Ling Peng ${ }^{1}$, Mengjie Jiang ${ }^{3}$, \\ Yemin Tang ${ }^{1}$ and Qiong Zhao ${ }^{1}$ \\ ${ }^{1}$ Department of Thoracic Oncology, The First Affiliated Hospital, College of Medicine, Zhejiang University, Hangzhou, Zhejiang \\ Province, 310003, China \\ ${ }^{2}$ Department of Gastroenterology, The First Affiliated Hospital, College of Medicine, Zhejiang University, Hangzhou, Zhejiang \\ Province, 310003, China \\ ${ }^{3}$ Department of Radiotherapy, The First Affiliated Hospital, College of Medicine, Zhejiang Traditional Chinese Medical \\ University, Hangzhou, Zhejiang Province, 310006, China \\ *These authors contributed equally to this work
}

Correspondence to: Qiong Zhao, email: 15700077397@139.com

Keywords: vitamin $D$, lung cancer, risk, survival

Received: March 27, 2017 Accepted: June 11, $2017 \quad$ Published: June 28, 2017

Copyright: Liu et al. This is an open-access article distributed under the terms of the Creative Commons Attribution License 3.0 (CC BY 3.0 ), which permits unrestricted use, distribution, and reproduction in any medium, provided the original author and source are credited.

\section{ABSTRACT}

In this meta-analysis, we analyzed the association between vitamin D levels and lung carcinoma risk and outcomes. Two authors independently searched the Web of Science, Pubmed, EBSCO and Ovid MEDLINE resources with the key words "vitamin $D$, lung cancer, solar and latitude" and enrolled 22 studies that satisfied the inclusion criteria. The summary odds ratios (ORs) with $95 \%$ confidence intervals (CIs) were calculated using the random (or fixed)-effects model. Potential confounders were carefully adjusted. High vitamin D (or calcium) intake and serum 25(OH)D levels each correlated inversely with lung cancer risk [OR $=0.72(95 \% \mathrm{CI}: 0.61-0.85, p<0.001)$ and $\mathrm{OR}=0.89(95 \% \mathrm{CI}: 0.83-0.97, p<0.05) \mathrm{J}$. High circulating 25(OH)D levels also reduced lung cancer mortality with the pooled OR reached 0.39 ( $95 \%$ CI: 0.28-0.54, $p<0.001)$ ]. A positive trend was presented in the relationship between serum 25( $\mathrm{OH})$ $D$ and survival $(O R=1.01,95 \% C I: 0.87-1.18, p=0.87)$. Subgroup analysis revealed that nonsmokers had higher vitamin $D$ levels, which correlated negatively with lung cancer risk (OR $=0.76,95 \% \mathrm{CI}: 0.65-0.88, p<0.01)$. Moreover, lower sun exposure and high latitude associated with lower vitamin $D$ levels. This meta-analysis shows that high vitamin D (or calcium) intake and serum 25(OH)D levels correlate with lower lung cancer risk and better prognosis. UVB and latitude may play a vital role in lung cancer occurrence and progression, although a direct evidence hasn't been obtained.

\section{INTRODUCTION}

Lung cancer is a major disease burden that accounts for 1.2 million deaths globally every year [1]. Although substantial effort has been invested in lung cancer research, therapeutic outcomes are poor. Recently, the role of vitamin D has been recognized in several tumors, including lung carcinoma.

The two main sources of vitamin D are endogenous synthesis in the skin regulated by sunlight exposure and dietary intake. Vitamin D is hydroxylated in the liver to 25-hydroxyvitamin D [25(OH)D], which is the major circulating form and determinant of vitamin D status [2]. The second hydroxylation reaction occurs in renal proximal tubules, where the primary active form of vitamin $\mathrm{D}, 1$, 25-dihydroxyvitamin $\mathrm{D}\left[1,25(\mathrm{OH})_{2} \mathrm{D}\right]$ is formed $[3,4]$. Compared to $1,25(\mathrm{OH})_{2} \mathrm{D}$, serum $25(\mathrm{OH}) \mathrm{D}$ is a better indicator of vitamin $\mathrm{D}$ status because of its longer half-life.

Vitamin D participates in critical cell functions such as cell proliferation, apoptosis, differentiation, metastasis, and angiogenesis [5-9]. Epidemiologic studies exploring the relationship between vitamin D and the incidence and 
prognosis of lung cancer patients have provided conflicting results [5, 10-13]. Zhang et al. [14] and Chen et al. [15] published two meta-analyses that demonstrated inverse association between blood vitamin D and lung cancer risk. However, the relationship between vitamin D (or calcium) intake and lung cancer is unclear. Recent studies have suggested that solar ultraviolet irradiation is protective against breast cancer, prostate cancer, non-Hodgkin lymphoma [16-19]. People living at various latitudes receive different doses of ultraviolet irradiation that regulates vitamin $\mathrm{D}$ synthesis and influences cancer risk and prognosis. Therefore, the aim of this systematic metaanalysis was to add the latest publications to understand the association between various factors regulating vitamin $\mathrm{D}$ levels and lung cancer risk and survival.

\section{RESULTS}

\section{Study selection}

After initial screening of 2122 abstracts that were identified from online research databases, 33 were considered for inclusion. After carefully reading the full texts, three studies were excluded because they were related to total cancer incidence or mortality rate [20-22]. Three other articles were excluded because they focused only on vitamin D receptor or gene polymorphisms [23-25]. Four publications [26-29] were excluded because they were repetitive studies of three other publications [30-32]. Two studies didn't provide the exact OR [25,33], and we obtained data from one of them from the authors [25]. Finally, 22 studies were selected for this meta-analysis. The flowchart of the study search and selection process is reported in Figure 1.

\section{Study characteristics}

The main characteristics of the 22 included studies are listed in Table 1. All eligible studies were published from 2005 to 2016 and included 813801 participants. Among the 22 studies, 8 were performed in Europe, 9 in North America, 4 in Asia and one in Oceania. Six of the 22 studies were case-control studies that included lung cancer patients of different stages and normal individuals undergoing routine physical examinations as controls. The remaining 16 studies were cohort studies that recruited general population during health check-ups. Fasting serum samples were collected at the time of recruitment. Patients were categorized into the following 4 categories based on serum 25(OH)D levels: (1) sufficient levels, $\geq$ $20 \mathrm{ng} / \mathrm{ml}(50 \mathrm{nmol} / \mathrm{L})$; (2) insufficient levels, 10-19.9 ng/ $\mathrm{ml}$ (25-49.9 nmol/L); (3) deficient levels, 5-9.9 ng/ml (12.5-24.9 nmol/L); (4) severe deficient levels, $<5 \mathrm{ng} / \mathrm{ml}$ $(12.5 \mathrm{nmol} / \mathrm{L})$. The enrolled papers exhibited moderate to high quality.

\section{Serum 25(OH)D levels and lung cancer risk}

There was a decreased lung cancer risk in patients when comparing the highest vs. lowest levels of circulating 25(OH) D $(\mathrm{OR}=0.93,95 \% \mathrm{CI}: 0.87-1.00, p<0.05)$ and heterogeneity $\mathrm{I}^{2}=61.3 \%, p=0.008$ (Supplementary Figure 1A). For the sensitivity analysis removal of the study by Skaaby et al. [34] reduced heterogeneity without significantly affecting OR $(\mathrm{OR}=0.72,95 \% \mathrm{CI}$ : $0.61-0.85$, $p<0.001 ; \mathrm{I}^{2}=25.5 \%, p=0.2255$; Figure $2 \mathrm{~A}$ ).

\section{Vitamin D intake and lung cancer risk}

Analysis of the 7 studies that evaluated the correlation between vitamin D (or calcium) intake and lung cancer risk showed pooled OR of 0.92 (95\% CI: $0.85-1.00, p<0.05)$ and heterogeneity $\mathrm{I}^{2}=64 \%, p=0.01$ (Figure 1B). The study by Zhou et al. [35] was eliminated by the sensitivity analysis and resulted in a pooled OR of 0.89 , 95\% CI: $0.83-0.97, p<0.01 ; \mathrm{I}^{2}=0 \%, p=0.46$ (Figure 2B).

Subgroup analysis based on smoking status demonstrated a negative association of lung cancer risk with nonsmokers $(\mathrm{OR}=0.76,95 \% \mathrm{CI}$ : 0.65-0.88, $p<0.01$; $\mathrm{I}^{2}=62.1 \%, p=0.07$; Figure $\left.3 \mathrm{~A}\right)$. However, there was no association with former smokers $(\mathrm{OR}=0.98$, 95\% CI: $\left.0.69-1.4, p=0.92 ; \mathrm{I}^{2}=70.9 \%, p=0.06\right)$ or current smokers $(\mathrm{OR}=1,95 \% \mathrm{CI}: 0.63-1.60, p=0.99$; $\mathrm{I}^{2}=0 \%, p=0.85$; Figure $\left.3 \mathrm{~B}-3 \mathrm{C}\right)$.

\section{Serum 25(OH)D levels and lung cancer survival}

The multivariable-adjusted ORs (highest vs. lowest categories of $25(\mathrm{OH}) \mathrm{D})$ of lung cancer survival and mortality with serum $25(\mathrm{OH}) \mathrm{D}$ are shown in Figure $4 \mathrm{~A}$ and Figure 4B. The pooled $\mathrm{OR}=1.01,95 \% \mathrm{CI}: 0.87-1.18$, $p=0.87 ; \mathrm{I}^{2}=19.4 \%, p=0.29$ for survival and $\mathrm{OR}=0.39$, 95\% CI: $0.28-0.54, p<0.01 ; \mathrm{I}^{2}=92.5 \%, p<0.01$ for mortality. Patients with high $25(\mathrm{OH}) \mathrm{D}$ levels tend to have a better prognosis.

\section{Publication bias and sensitivity analysis}

Symmetrical funnel plots demonstrated that there was no publication bias in this meta-analysis (Supplementary Figure 2). Further, sensitivity analysis by removing single study in turns exhibited no disproportionate impact on the pooled estimates, which indicated the robustness of our research.

\section{Latitude, annual sunshine exposure, vitamin D and lung cancer}

Some studies showed a positive correlation between the incidence of lung cancer and latitude [36, 37]. Lin et al. found that UVR exposure was associated with decreased 
Table 1: Characteristics of the selected studies

\begin{tabular}{|c|c|c|c|c|c|c|c|c|c|c|c|c|c|}
\hline \multirow[b]{2}{*}{ Serum vitamin $D$ and risk } & \multirow[t]{2}{*}{ OR } & \multicolumn{2}{|c|}{$95 \% \mathrm{CI}$} & \multirow[t]{2}{*}{ Country } & \multirow[t]{2}{*}{$\begin{array}{l}\text { Follow-up } \\
\text { period }\end{array}$} & \multirow[t]{2}{*}{$\begin{array}{c}\text { Age } \\
\text { (years) }\end{array}$} & \multirow[t]{2}{*}{ Sex } & \multicolumn{3}{|c|}{ Smokers (\%) } & \multirow[t]{2}{*}{ Partipants } & \multirow[t]{2}{*}{$\begin{array}{l}\text { Lung } \\
\text { cancer } \\
\text { cases }\end{array}$} & \multirow[t]{2}{*}{ Measuremen } \\
\hline & & & & & & & & & & & & & \\
\hline Kilkkinen, A. 2008 [82] & 0.72 & 0.43 & 1.19 & Finland & $24 \mathrm{y}$ & 49.6 & Both & NG & $C: 29.6$ & NG & 6,937 & 122 & RIA \\
\hline Weinstein, S.J. 2011 [83] & 0.91 & 0.48 & 1.72 & Finland & $20 \mathrm{y}$ & 59 & Male & NG & $\mathrm{C}: 100$ & NG & 29,133 & 500 & CLIA \\
\hline Afzal, S. 2013 [74] & 0.57 & 0.43 & 0.75 & Denmark & $28 \mathrm{y}$ & 58 & Both & \multicolumn{3}{|c|}{ Ever smoker: 3.3} & 9,791 & 507 & CLIA \\
\hline $\begin{array}{l}\text { Skaaby, T. } 2014 \\
\text { (Monica10) [34] }\end{array}$ & & & & & & $40-71$ & Both & $F: 27.4$ & $\mathrm{C}: 45.2$ & O:0.9 & 2,649 & 84 & CTIA \\
\hline $\begin{array}{l}\text { Skaaby, T. } 2014 \text { (Inter99) } \\
{[34]}\end{array}$ & 0.91 & 0.51 & 1,62 & Denmark & $11.3 \mathrm{y}$ & $30-60$ & Both & $F: 25.5$ & $\mathrm{C}: 35.2$ & $0: 3.5$ & 6,146 & 36 & HPLC \\
\hline $\begin{array}{l}\text { Skaaby, T. } 2014 \\
\text { (Health2006) [34] }\end{array}$ & & & & & & $18-69$ & Both & $F: 32.3$ & $\mathrm{C}: 22.2$ & $0: 3.2$ & 3,409 & 6 & ECLIA \\
\hline Wong, Y.Y. 2014 [76] & 0.99 & 0.59 & 1,68 & Australia & $6.7 \mathrm{y}$ & 77.9 & Male & $F: 61.4$ & C:5.04 & NG & 4,208 & 101 & CLIA \\
\hline Wang, X. 2015 [75] & 0.41 & 0.19 & 0.91 & China & NG & 57.1 & Both & $F: 20$ & $\mathrm{C}: 48$ & NG & 200 & 100 & $\mathrm{LC} / \mathrm{MS} / \mathrm{MS}$ \\
\hline $\begin{array}{l}\text { Ordonez-Mena, J.M. } 2016 \\
\text { (ESTHER) [31] }\end{array}$ & 1.07 & 0.64 & 1.78 & Germany & $10 \mathrm{y}$ & 63 & Both & $F: 31.6$ & C: 16.5 & NG & 8,928 & 134 & CLIA \\
\hline $\begin{array}{l}\text { Ordonez-Mena, J.M. } 2016 \\
\text { (TROMSØ) [31] }\end{array}$ & 1.07 & 0.64 & 1.78 & Germany & $10 \mathrm{y}$ & 63 & Both & $F: 31.6$ & $\mathrm{C}: 16.5$ & NG & 8,928 & 134 & CLIA \\
\hline Wu, X. 2016 [25] & 0.74 & 0.51 & 1.19 & China & NG & 57.4 & Both & NG & C:59.1 & NG & 871 & 426 & RIA \\
\hline \multicolumn{14}{|l|}{ Vitamin D intake and risk } \\
\hline Yumie Takata 2012 [30] & 0.66 & 0.48 & 0.91 & China & $11.2 \mathrm{y}$ & 59.1 & Female & NG & NG & NG & 71,267 & 428 & NG \\
\hline Cheng, T. Y. 2013 [84] & 0.92 & 0.69 & 1.21 & USA & $7 y$ & 63 & Female & $F: 40.3$ & C:7.3 & NG & 128,779 & 1,771 & NG \\
\hline \multicolumn{14}{|l|}{ Vitamin D intake and risk } \\
\hline Cheng, T. Y. 2014 [85] & 0.67 & 0.32 & 1.39 & USA & $4 \mathrm{y}$ & 60.8 & Both & $F: 70.4$ & $\mathrm{C} 29.6$ & NG & 1,428 & 749 & NG \\
\hline Redaniel, M. T. 2014 [86] & 0.89 & 0.7 & 1.13 & UK & $5 \mathrm{y}$ & $>55$ & Female & $F: 23.3$ & C:58.1 & NG & 6,750 & 484 & NG \\
\hline Mahabir, S. 2010 [87] & 0.92 & 0.84 & 1.01 & USA & $7 y$ & $50-71$ & Both & $F: 49.0$ & $\mathrm{C}: 12$ & NG & 482,875 & 7,052 & NG \\
\hline Li, K. $2011[88]$ & 0.71 & 0.14 & 1.21 & German & $11 \mathrm{y}$ & $35-64$ & Both & NG & NG & NG & 24,323 & 147 & NG \\
\hline Zhou, Wei 2005 [35] & 1.64 & 1.17 & 2.29 & USA & NG & 66 & NG & $F: 5.7$ & $\mathrm{C}: 4.4$ & NG & 2,048 & 923 & NG \\
\hline \multicolumn{14}{|c|}{ Serum vitamin D and survival } \\
\hline Zhou, W. 2007 [61] & 0.74 & 0.5 & 1.1 & USA & $72 \mathrm{~m}$ & 68.6 & Both & $\mathrm{F}: 48.8$ & $\mathrm{C}: 33.8$ & NG & NG & 447 & RIA \\
\hline Heist, R. S. 2008 [24] & 1.08 & 0.75 & 1.57 & USA & $42 \mathrm{~m}$ & 62 & Both & $\mathrm{F}: 45$ & C: 47 & NG & NG & 294 & RIA \\
\hline Anic, G. M. 2014 [23] & 1.18 & 0.89 & 1.56 & Finland & NG & 58.6 & Male & NG & $\mathrm{C}: 100$ & NG & NG & 500 & CLIA \\
\hline Vashi, P. G. 2015 [77] & 0.99 & 0.78 & 1.26 & USA & $10.8 \mathrm{~m}$ & 57.4 & Both & $F: 39.8$ & C:39.8 & NG & NG & 359 & CLIA \\
\hline \multicolumn{14}{|c|}{ Serum vitamin D and mortality } \\
\hline Liu, Y. 2011 [89] & 2.54 & 1.01 & 6.41 & China & $72 \mathrm{~m}$ & NG & Both & NG & NG & NG & NG & 568 & ELISA \\
\hline Cheng, T. Y. 2012 [32] & 0.53 & 0.31 & 0.92 & USA & $12 \mathrm{y}$ & 43.7 & Both & $F: 23.7$ & $\mathrm{C}: 25.0$ & NG & 16,693 & 258 & RIA \\
\hline Tretli, S. 2012 [90] & 0.18 & 0.11 & 0.29 & Norwegian & NG & 56.5 & Both & NG & NG & NG & 658 & 210 & RIA \\
\hline
\end{tabular}

risk of lung cancer $[\mathrm{H} R=0.86(0.75,0.98), p<0.5]$ [38]. A Chinese study exhibited a $12 \%$ decrease in lung cancer mortality for every $10 \mathrm{~mW} /\left(\mathrm{nm} / \mathrm{m}^{2}\right)$ increase in UVB irradiance [39]. Due to insufficient data sources and high heterogeneity in available data, we failed to statistically prove that higher latitude and lower sun exposure resulted in higher incidence and mortality of lung cancer. Vitamin D synthesis partly relies on exposure to solar ultraviolet radiation, which is affected by duration of daily sunshine, latitude and season [40]. We compared vitamin D levels with annual sunshine exposure and latitude of the cities where the included researches were conducted. As expected, we discovered a positive relationship between vitamin $\mathrm{D}$ concentrations and annual sun exposure $(r=0.807, p<0.001)$ and a negative correlation between vitamin D levels and latitude $(r=-0.62, p<0.01)$. This outcome indirectly verified our hypothesis.

\section{DISCUSSION}

In this meta-analysis, we comprehensively analyzed the relationship between vitamin D levels and lung cancer. Our results demonstrated an inverse association between serum $25(\mathrm{OH}) \mathrm{D}$ levels and lung cancer risk, which was consistent with findings by previous two meta-analyses [14]. Vitamin D (or calcium) intake was also negatively 
related to lung cancer risk. Subgroup analysis showed that vitamin D intake reduced lung cancer risk, especially in nonsmokers. Besides, a trend presented that high serum vitamin D levels reduced lung cancer mortality and improved survival. In relation to annual sun exposure and latitude, vitamin D levels positively correlated with extent of sun exposure, but negatively correlated with latitude.

Several possible mechanisms can explain the protective effects of vitamin D against lung cancer. Some studies have demonstrated that vitamin $\mathrm{D}$ regulates immunological function of lung epithelial cells and inhibits cellular proliferation and angiogenesis while promoting cellular differentiation and apoptosis [41-44].
It can enhance host defense by facilitating transcription of cathelicidin antimicrobial peptide genes and translation of CD14, a co-receptor for detecting bacterial lipopolysaccharide, both of which are vital for innate immunity in the lung [41]. In human lung tumor cell lines and mouse models, $1,25(\mathrm{OH})_{2} \mathrm{D}$ inhibits the angiogenesis and growth of cancer cells by suppressing the response to vascular endothelial growth factor (VEGF) [43]. Also, $1,25(\mathrm{OH})_{2} \mathrm{D}$ inhibits signaling pathways that promote lung cancer including mutations in K-Ras and epidermal growth factor receptor (EGFR), dysregulation of $\mathrm{Wnt} / \beta$-catenin, which determines metastasis and proliferation $[5,45,46]$. In addition, $1,25(\mathrm{OH})_{2} \mathrm{D}$ upregulates secretion of

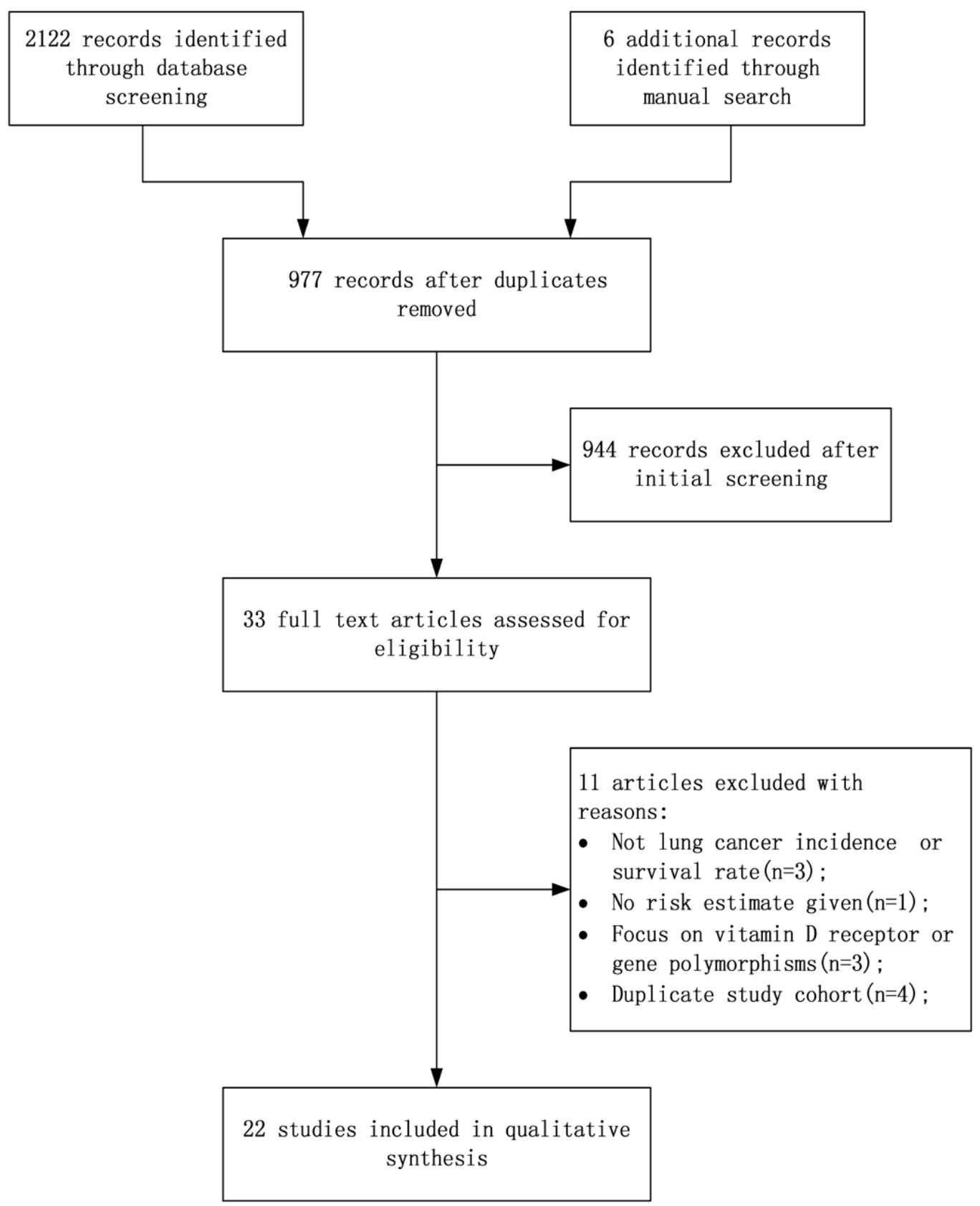

Figure 1: Flow diagram of study selection process. 
E-cadherin and catenin, a glycoprotein that helps cell-cell adherence, thereby preventing metastases [47]. Moreover, $1,25(\mathrm{OH})_{2} \mathrm{D}$ represses the expression of cyclooxygenase- 2 and inhibits prostaglandin synthesis, which can stimulate tumor cell proliferation and angiogenesis [48]. Finally, both lung cancer and chronic obstructive pulmonary disease (COPD) involve DNA damage, epithelial-to-mesenchymal transition (EMT) and airway inflammatory mechanisms $[49,50]$. Skaaby et al. found inverse relationship between vitamin $\mathrm{D}$ status and COPD, thereby suggesting its association with lung cancer [51].

Subgroup analyses showed that vitamin D reduced lung cancer risk in non-smokers but not former or current smokers. Smokers had lower vitamin D intake $[52,53]$ and serum 25(OH)D levels [54-56]. Besides, 1,25(OH) 2 is degraded by CYP24A1, a chemical substance that is activated by smoke-related carcinogen benzo[a]pyrene [57]. Therefore, higher serum vitamin D concentration or vitamin $\mathrm{D}$ intake may not have a positive biological effect among current smokers. We found a beneficial trend for higher vitamin D levels in former smokers than current smokers. This supports previous findings that quitting smoking increases both vitamin $\mathrm{D}$ intake and serum vitamin D status closer to levels of never smokers [58, 59]. It is plausible that smoking cessation restores metabolic functions of vitamin D.

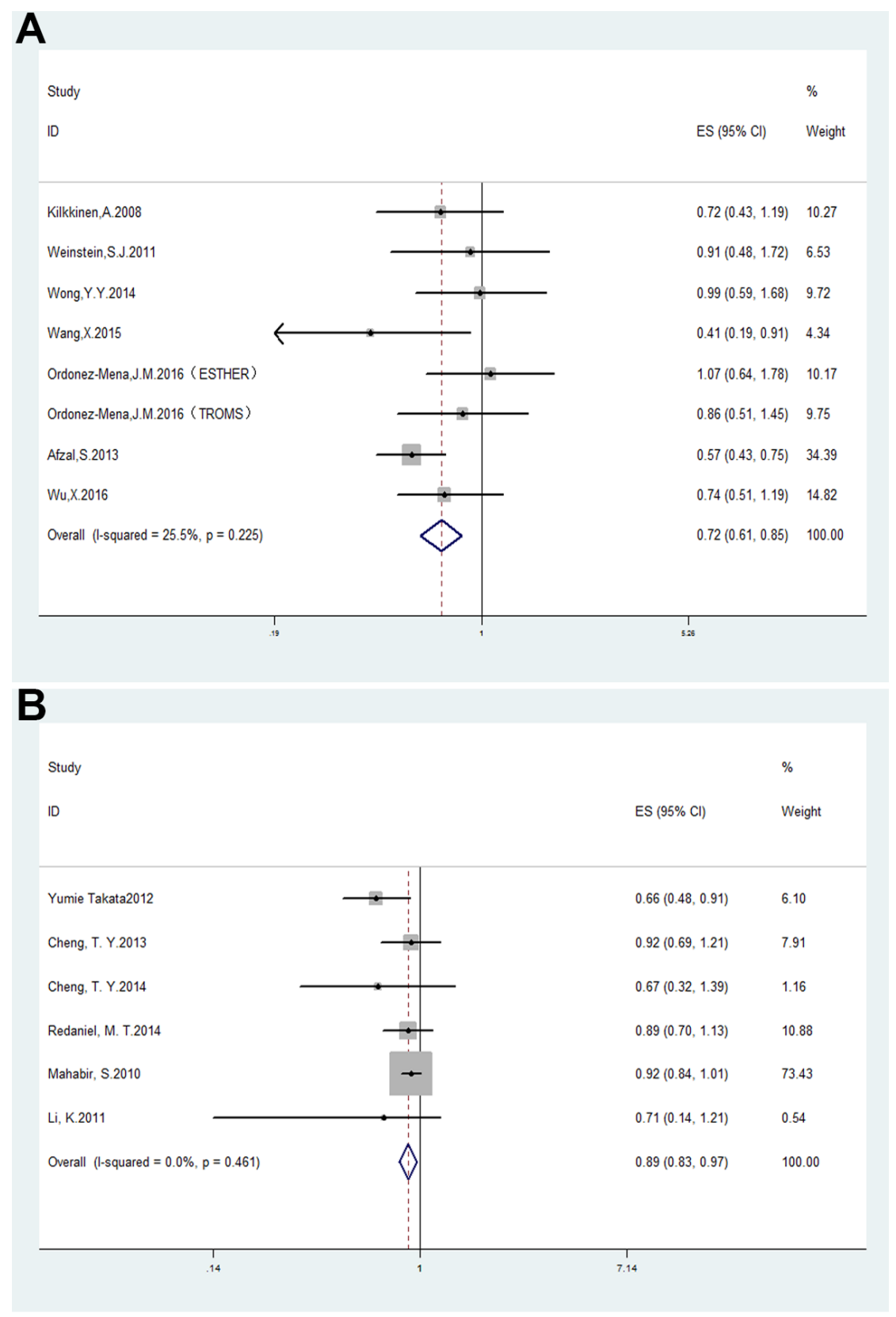

Figure 2: Forest plots analyzing (A) serum vitamin D levels and lung cancer risk; and (B) vitamin D dietary intake and lung cancer risk. 


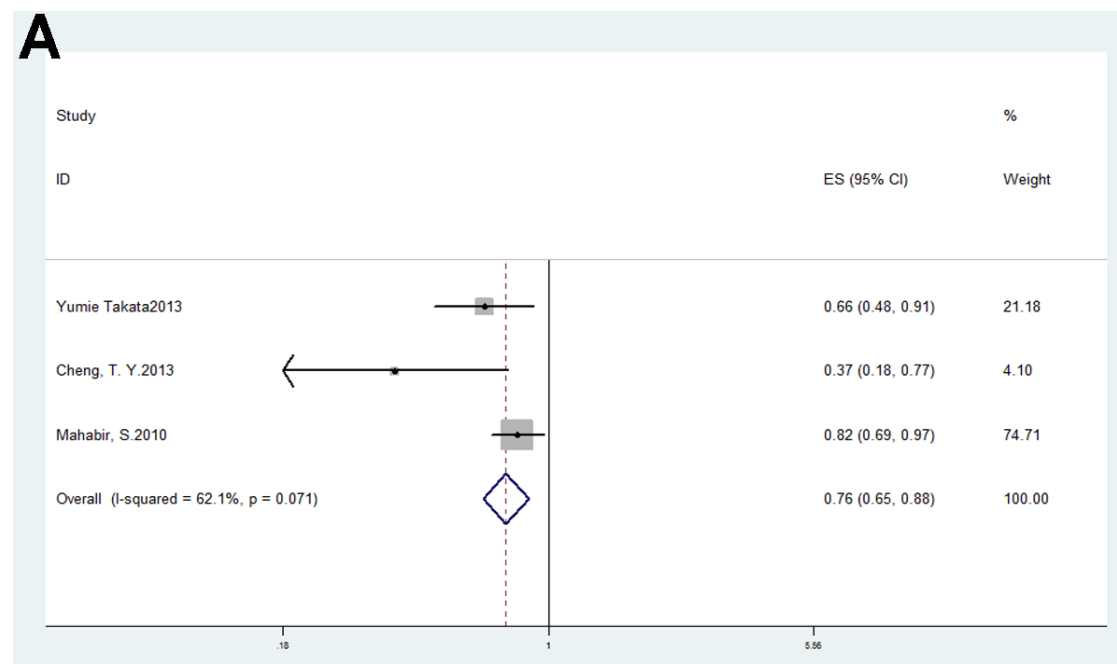

\section{B}

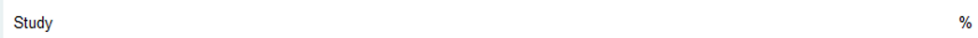

ID

ES $(95 \% \mathrm{Cl}) \quad$ Weight

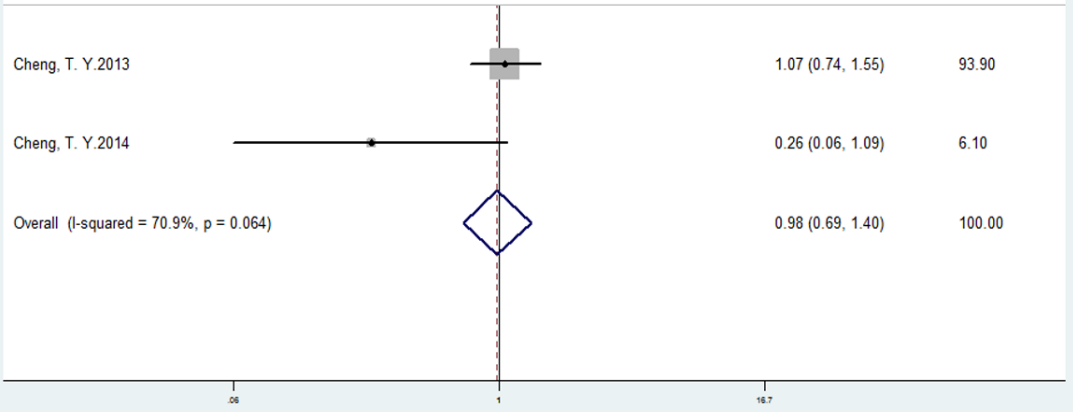

C

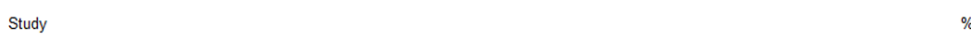

ID $\quad$ ES $(95 \% \mathrm{Cl}) \quad$ Weight

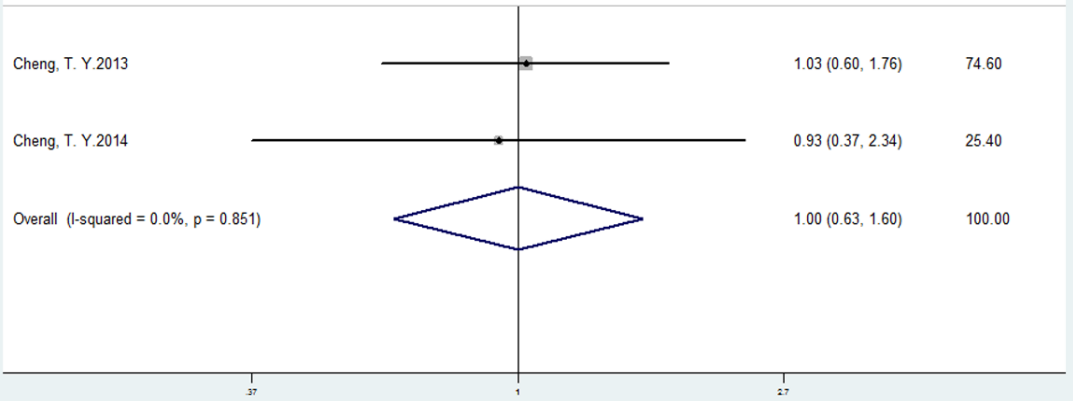

Figure 3: Forest plots of subgroup analysis of vitamin D intake and lung cancer risk in (A) nonsmokers; (B) former smokers and (C) current smokers. 
Interestingly, there was no association between blood vitamin D levels with lung cancer survival in our analysis. There are several possible reasons to explain this finding. First, the vitamin D concentrations in our study were too low (average value $=17.7 \mathrm{ng} / \mathrm{ml}$ ) to observe any significant impact on the prognosis. Clinically, vitamin D levels below $20 \mathrm{ng} / \mathrm{ml}$ are considered deficient [60]. Less physical activity, insufficient sunlight exposure and high latitude related to these chosen studies may account for low vitamin D levels. There is probably a threshold effect for serum vitamin $\mathrm{D}$ or differential effects for vitamin D from foods and supplements in regard to lung cancer prognosis. Second, the disease stage was far too advanced in the selected patients for vitamin D levels to influence prognosis. A US study collected serum samples from 447 early stage non-small cell lung cancer patients shortly after diagnosis and found higher circulating $25(\mathrm{OH}) \mathrm{D}$ correlated with longer survival, especially among early stage IBIIB patients (AHR, $0.45 ; 95 \%$ CI, 0.24-0.82; $p=0.002$ ) [61]. We can assume that malignant cells decreased the expression of vitamin $\mathrm{D}$ receptor or conversion of $25(\mathrm{OH}) \mathrm{D}$ to $1,25(\mathrm{OH})_{2} \mathrm{D}$ to escape the antiproliferative actions of vitamin $\mathrm{D}$, and this may be more prevalent in advanced-stage cancers than earlier stages [62]. Thirdly, the various histological types of lung cancer in the selected studies may respond differently to vitamin D. Vitamin D suppressed growth of a lung squamous cell carcinoma (SCC) cell line, but not an adenocarcinoma cell line with higher vitamin D receptor mRNA levels in the SCC cell line compared to the adenocarcinoma cell line [63]. Lastly, vitamin D may not influence prognosis in advanced lung cancer patients.

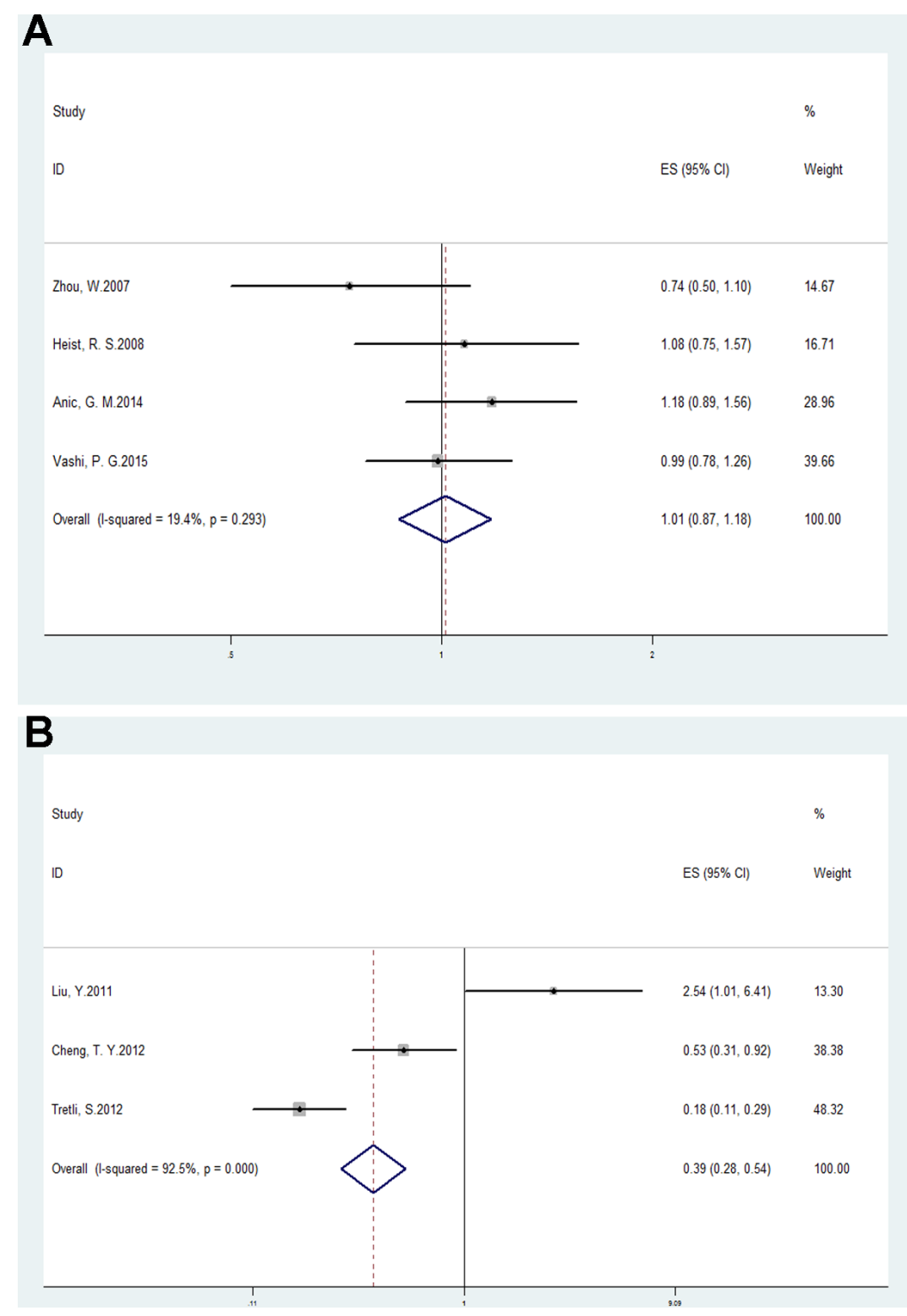

Figure 4: Forest plots analyzing (A) serum vitamin D values and lung cancer survival; and (B) serum vitamin D values and lung cancer mortality. 
Consistent with previous findings [64-66], we observed that poor sun exposure or high latitude resulted in reduced serum vitamin D levels. Latitude-dependent variability in the solar zenith angle and higher ozone columns far from the equator may contribute to this variation in UVB irradiation, thereby influencing variation in vitamin D production [66]. We further postulate that latitude, sun radiation and lung cancer may be linked through of the metabolic role of vitamin $\mathrm{D}$ or other unknown mechanisms. More studies are necessary to confirm these aspects conclusively.

Our study has few inherent potential limitations that should be considered. First, the selected studies evaluated circulating 25(OH)D levels with different measurements, and the time (time quantum, season) of collecting blood sample was not always consistent. Second, a metaanalysis of observational studies cannot fully explain the causative relation between vitamin D and lung cancer. As most of the included articles were prospective cohort studies and serum samples were collected at the time of initial recruitment, from a point we can assure it is low vitamin D leads to lung cancer, not the reverse causation. Third, Skaaby et al. reported that high physical activity, lower BMI, non-smoking, a healthier diet and higher alcohol intake were associated with higher 25(OH)D levels [56]. The original studies had already adjusted for such covariates and bias introduced by these potential confounding factors was probably minimized. Fourth, the quartiles for highest vs. lowest vitamin D categories varied among the different studies, which was an inherent bias in the quantitative assessment. Fifth, even though we attempted to perform our literature search as completely as possible, we were unable to obtain unpublished papers and our search language was restricted to English only. Despite these limitations, no significant heterogeneity was found, thereby indicating robustness of our meta-analysis. Also, funnel plot analysis didn't discover any publication bias, suggesting that the studies used for this analysis were representative of clinical circumstances.

In conclusion, our meta-analysis suggests that higher serum $25(\mathrm{OH}) \mathrm{D}$ and vitamin D intake is negatively linked with lung cancer incidence. Since sun exposure and latitudes affect vitamin D levels, our meta-analysis hints at their relationship with lung cancer, although more investigations are needed regarding this aspect. Also, well-designed randomized controlled trials are needed to explore the specific mechanistic relationship between vitamin $\mathrm{D}$ and lung cancer prognosis.

\section{MATERIALS AND METHODS}

\section{Search strategy}

We searched relevant studies in computerized bibliographic databases, namely, Pubmed, Web of Science, EBSCO and Ovid MEDLINE. The language parameter for study search was set to English. The search terms were vitamin $\mathrm{D}, 25(\mathrm{OH}) \mathrm{D}, 1,25(\mathrm{OH})_{2} \mathrm{D}$, lung cancer, solar and latitude. The last comprehensive search was performed on March 13, 2017. All cited references were also manually crosschecked for additional reports.

\section{Study inclusion criteria and exclusion criteria}

The inclusion criteria for the studies were: (1) studies conducted on human populations and published in a peer-reviewed journal; (2) studies included case-control, cross-sectional, retrospective and prospective cohorts and assessed association between solar radiation, latitude, vitamin D [vitamin D (or calcium) intake or serum $25(\mathrm{OH}) \mathrm{D}]$ and lung cancer risk, survival and mortality; (3) studies reported OR, hazard ratio (HR) or relative risk (RR) with 95\% CI; (4) univariate or multivariate analyses was performed to analyze potential confounders including age, living circumstance, body mass index, smoking status, years and pack years of smoking, education, physical activity, family history of lung cancer and alcohol consumption; (5) only the most comprehensive study was retrieved for overlapping publications.

The major exclusion criteria were as follows: (1) articles did not satisfy the above-mentioned inclusion criteria; (2) articles were case reports, letters, proceedings, abstracts, editorials or reviews; (3) unpublished sources of data.

\section{Data extraction and quality assessment}

The following information was collected from each study: year of publication, first author, country, age, sex, number of participants, number of lung cancer cases and smokers, vitamin D levels, years of follow-up, OR (or RR, HR) and its 95\% CI.

The quality of the selected studies was analyzed using the Newcastle-Ottawa Scale [67]. The literature selection, methodological quality assessment and data extraction process was conducted separately by two experienced reviewers and any disagreement was resolved by a third reviewer. This meta-analysis was performed in compliance with the Preferred Reporting Items for Systematic reviews and Meta-Analyses (PRISMA) guidelines [68] (Supplementary Table 1).

\section{Statistical analysis}

Since the absolute lung cancer risk is relatively low, the RR and HR were mathematically equal to OR $[69,70]$ and therefore, we treated all results as OR [71]. The reported OR with their corresponding 95\% CIs comparing highest and lowest levels of vitamin D were used to calculate pooled estimates for the meta-analysis (the lowest level category was the reference). If the original paper didn't use the lowest exposure level as the reference, 
the OR were recalculated with the method according to Greenland et al. [72] and Orsini et al. [73]. Therefore, raw data from 5 reports were recounted [31, 74-77].

The pooled OR and 95\% CI were calculated by using fixed effects model according to generic inverse variance or random effects model using the DerSimonianLaird method based on heterogeneity [78]. Heterogeneity was evaluated by employing the Cochran Q test with a $P$ value greater than 0.05 suggesting no obvious heterogeneity [79]. The $\mathrm{I}^{2}$ test was also used to assess the heterogeneity between studies. $\mathrm{I}^{2}$ values of 25,50 , and $75 \%$ indicated low, moderate, and high heterogeneity, respectively [80]. When $\mathrm{I}^{2}$ was under $50 \%$, studies with a relatively acceptable heterogeneity were considered, and the fixed-effects model was adopted; otherwise, a random effect model was employed. We also performed sensitivity analysis to explore the stability condition of pooled estimates by omitting single study at a time. Further, visual inspection of the funnel plot was used to detect the possible risk of publication bias [81]. The Spearman linear correlation analysis was used to analyze the relations between annual sunshine exposure, latitude and vitamin D. All meta- analyses were conducted with the STATA 12.0 (Stata Corporation, College Station, TX, USA) and RevMan 5.3 software (Cochrane Library, Oxford, UK). Spearman linear correlation analysis was operated with SPSS 17.0 (IBM, Chicago, IL, USA).

\section{ACKNOWLEDGMENTS AND FUNDING}

This study was supported by grants from the Public Technology Research and Social Development Projects of Zhejiang province (2014C33206).

\section{CONFLICTS OF INTEREST}

The authors have no conflicts of interest to disclose.

\section{REFERENCES}

1. Curado MP, Edwards B, Shin HR, Storm H, Ferlay J, Heanue M, Boyle P. (2007). Cancer incidence in five continents, Volume IX: IARC Press, International Agency for Research on Cancer.

2. Holick MF. Vitamin D: its role in cancer prevention and treatment. Prog Biophys Mol Biol. 2006; 92:49-59. doi: 10.1016/j.pbiomolbio.2006.02.014.

3. Adams JS, Hewison M. Update in vitamin D. J Clin Endocrinol Metab. 2010; 95:471-8. doi: 10.1210/jc.2009-1773.

4. Holick MF. Vitamin D deficiency. N Engl J Med. 2007; 357:266-81. doi: 10.1056/NEJMra070553.

5. Deeb KK, Trump DL, Johnson CS. Vitamin D signalling pathways in cancer: potential for anticancer therapeutics. Nat Rev Cancer. 2007; 7:684-700. doi: 10.1038/nrc2196.
6. Hanahan D, Weinberg RA. Hallmarks of cancer: the next generation. Cell. 2011; 144:646-74. doi: 10.1016/j. cell.2011.02.013.

7. Diaz GD, Paraskeva C, Thomas MG, Binderup L, Hague A. Apoptosis is induced by the active metabolite of vitamin D3 and its analogue EB1089 in colorectal adenoma and carcinoma cells: possible implications for prevention and therapy. Cancer Res. 2000; 60:2304-12.

8. Fernandez-Garcia NI, Palmer HG, Garcia M, GonzalezMartin A, del Rio M, Barettino D, Volpert O, Munoz A, Jimenez B. 1alpha,25-Dihydroxyvitamin D3 regulates the expression of Id 1 and Id 2 genes and the angiogenic phenotype of human colon carcinoma cells. Oncogene. 2005; 24:6533-44. doi: 10.1038/sj.onc.1208801.

9. Evans SR, Shchepotin EI, Young H, Rochon J, Uskokovic M, Shchepotin IB. 1,25-dihydroxyvitamin D3 synthetic analogs inhibit spontaneous metastases in a 1,2-dimethylhydrazine-induced colon carcinogenesis model. Int J Oncol. 2000; 16:1249-54.

10. Feldman D, Krishnan AV, Swami S, Giovannucci E, Feldman BJ. The role of vitamin D in reducing cancer risk and progression. Nat Rev Cancer. 2014; 14:342-57. doi: $10.1038 / \operatorname{nrc} 3691$.

11. Gandini S, Boniol M, Haukka J, Byrnes G, Cox B, Sneyd MJ, Mullie P, Autier P. Meta-analysis of observational studies of serum 25-hydroxyvitamin D levels and colorectal, breast and prostate cancer and colorectal adenoma. Int $\mathrm{J}$ Cancer. 2011; 128:1414-24. doi: 10.1002/ijc.25439.

12. Jacobs ET, Hibler EA, Lance P, Sardo CL, Jurutka PW. Association between circulating concentrations of $25(\mathrm{OH})$ $\mathrm{D}$ and colorectal adenoma: a pooled analysis. Int J Cancer. 2013; 133:2980-8. doi: 10.1002/ijc.28316.

13. Chen F, Li Q, Yu Y, Yang W, Shi F, Qu Y. Association of vitamin $\mathrm{C}$, vitamin $\mathrm{D}$, vitamin $\mathrm{E}$ and risk of bladder cancer: a dose-response meta-analysis. Sci Rep. 2015; 5: 9599. doi: 10.1038/srep09599.

14. Zhang L, Wang S, Che X, Li X. Vitamin D and lung cancer risk: a comprehensive review and metaanalysis. Cell Physiol Biochem. 2015; 36:299-305. doi: 10.1159/000374072.

15. Chen GC, Zhang ZL, Wan Z, Wang L, Weber P, Eggersdorfer M, Qin LQ, Zhang W. Circulating 25-hydroxyvitamin D and risk of lung cancer: a doseresponse meta-analysis. Cancer Causes Control. 2015; 26:1719-28. doi: 10.1007/s10552-015-0665-6.

16. Kricker A, Armstrong BK, Hughes AM, Goumas C, Smedby KE, Zheng T, Spinelli JJ, De Sanjose S, Hartge P, Melbye M, Willett EV, Becker N, Chiu BC, et al. Personal sun exposure and risk of non Hodgkin lymphoma: a pooled analysis from the Interlymph Consortium. Int $\mathrm{J}$ Cancer. 2008; 122:144-54. doi: 10.1002/ijc.23003.

17. Grant WB. Ecological studies of the UVB-vitamin D-cancer hypothesis. Anticancer Res. 2012; 32:223-36. 
18. Knight JA, Lesosky M, Barnett H, Raboud JM, Vieth R. Vitamin D and reduced risk of breast cancer: a populationbased case-control study. Cancer Epidemiol Biomarkers Prev. 2007; 16:422-9. doi: 10.1158/1055-9965.epi-06-0865.

19. Moon SJ, Fryer AA, Strange RC. Ultraviolet radiation: effects on risks of prostate cancer and other internal cancers. Mutat Res. 2005; 571:207-19. doi: 10.1016/j.mrfmmm.2004.09.015.

20. Giovannucci E, Liu Y, Rimm EB, Hollis BW, Fuchs CS, Stampfer MJ, Willett WC. Prospective study of predictors of vitamin D status and cancer incidence and mortality in men. J Natl Cancer Inst. 2006; 98:451-9. doi: 10.1093/jnci/djj101.

21. Giovannucci E, Liu Y, Willett WC. Cancer incidence and mortality and vitamin D in black and white male health professionals. Cancer Epidemiol Biomarkers Prev. 2006; 15:2467-72. doi: 10.1158/1055-9965.EPI-06-0357.

22. Grant WB. The likely role of vitamin D from solar ultraviolet-B irradiance in increasing cancer survival. Anticancer Res. 2006; 26:2605-14.

23. Anic GM, Weinstein SJ, Mondul AM, Mannisto S, Albanes D. Serum vitamin D, vitamin D binding protein, and lung cancer survival. Lung Cancer. 2014; 86:297-303. doi: 10.1016/j.lungcan.2014.10.008.

24. Heist RS, Zhou W, Wang Z, Liu G, Neuberg D, Su L, Asomaning K, Hollis BW, Lynch TJ, Wain JC, Giovannucci E, Christiani DC. Circulating 25-hydroxyvitamin D, VDR polymorphisms, and survival in advanced non-small-cell lung cancer. J Clin Oncol. 2008; 26:5596-602. doi: 10.1200/JCO.2008.18.0406.

25. Wu X, Cheng J, Yang K. Vitamin D-Related Gene Polymorphisms, Plasma 25-Hydroxy-Vitamin D, Cigarette Smoke and Non-Small Cell Lung Cancer (NSCLC) Risk. Int J Mol Sci. 2016; 17. doi: 10.3390/ijms17101597.

26. Freedman DM, Looker AC, Abnet CC, Linet $\mathrm{MS}$, Graubard BI. Serum 25-hydroxyvitamin D and cancer mortality in the NHANES III study (1988-2006). Cancer Res. 2010; 70:8587-97. doi: 10.1158/0008-5472.CAN-10-1420.

27. Ordonez-Mena JM, Schottker B, Haug U, Muller H, Kohrle J, Schomburg L, Holleczek B, Brenner H. Serum 25-hydroxyvitamin $\mathrm{d}$ and cancer risk in older adults: results from a large German prospective cohort study. Cancer Epidemiol Biomarkers Prev. 2013; 22:905-16. doi: 10.1158/1055-9965.EPI-12-1332.

28. Park Y, Leitzmann MF, Subar AF, Hollenbeck A, Schatzkin A. Dairy food, calcium, and risk of cancer in the NIH-AARP Diet and Health Study. Arch Intern Med. 2009; 169:391-401. doi: 10.1001/archinternmed.2008.578.

29. Freedman DM, Looker AC, Chang SC, Graubard BI. Prospective study of serum vitamin D and cancer mortality in the United States. J Natl Cancer Inst. 2007; 99:1594-602. doi: 10.1093/jnci/djm204.

30. Takata Y, Shu XO, Yang G, Li H, Dai Q, Gao J, Cai Q, Gao YT, Zheng W. Calcium Intake and Lung Cancer Risk Among Female Nonsmokers: A Report from the Shanghai
Women's Health Study. Cancer Epidemiol Biomarkers Prev. 2012; 22:50-7. doi: 10.1158/1055-9965.epi-120915-t.

31. Ordonez-Mena JM, Schottker B, Fedirko V, Jenab M, Olsen A, Halkjaer J, Kampman E, de Groot L, Jansen E, Bueno-de-Mesquita HB, Peeters PH, Siganos G, Wilsgaard T, et al. Pre-diagnostic vitamin D concentrations and cancer risks in older individuals: an analysis of cohorts participating in the CHANCES consortium. Eur J Epidemiol. 2016; 31:311-23. doi: 10.1007/s10654-015-0040-7.

32. Cheng TY, Neuhouser ML. Serum 25-hydroxyvitamin D, vitamin A, and lung cancer mortality in the US population: a potential nutrient-nutrient interaction. Cancer Causes Control. 2012; 23:1557-65. doi: 10.1007/s10552-012-0033-8.

33. Porojnicu AC, Robsahm TE, Dahlback A, Berg JP, Christiani D, Bruland OS, Moan J. Seasonal and geographical variations in lung cancer prognosis in Norway. Does Vitamin D from the sun play a role? Lung Cancer. 2007; 55:263-70. doi: 10.1016/j.lungcan.2006.11.013.

34. Skaaby T, Husemoen LL, Thuesen BH, Pisinger C, Jorgensen T, Roswall N, Larsen SC, Linneberg A. Prospective population-based study of the association between serum 25-hydroxyvitamin-D levels and the incidence of specific types of cancer. Cancer Epidemiol Biomarkers Prev. 2014; 23:1220-9. doi: 10.1158/1055-9965. EPI-14-0007.

35. Zhou W, Park S, Liu G, Miller DP, Wang LI, Pothier L, Wain JC, Lynch TJ, Giovannucci E, Christiani DC. Dietary Iron, Zinc, and Calcium and the Risk of Lung Cancer. Epidemiology. 2005; 16:772-9. doi: 10.1097/01. ede.0000181311.11585.59.

36. Grant WB. An ecological study of cancer mortality rates in the United States with respect to solar ultraviolet-B doses, smoking, alcohol consumption and urban/rural residence. Dermatoendocrinol. 2010; 2:68-76. doi: 10.4161/ derm.2.2.13812.

37. Grant WB. A multicountry ecological study of cancer incidence rates in 2008 with respect to various riskmodifying factors. Nutrients. 2013; 6:163-89. doi: 10.3390/ nu6010163.

38. Lin SW, Wheeler DC, Park Y, Cahoon EK, Hollenbeck AR, Freedman DM, Abnet CC. Prospective study of ultraviolet radiation exposure and risk of cancer in the United States. Int J Cancer. 2012; 131: E1015-23. doi: 10.1002/ijc.27619.

39. Chen W, Clements M, Rahman B, Zhang S, Qiao Y, Armstrong BK. Relationship between cancer mortality/ incidence and ambient ultraviolet B irradiance in China. Cancer Causes Control. 2010; 21:1701-9. doi: 10.1007/ s10552-010-9599-1.

40. Holick MF. Environmental factors that influence the cutaneous production of vitamin D. Am J Clin Nutr. 1995; 61:638s-45s.

41. Hansdottir S, Monick MM, Hinde SL, Lovan N, Look DC, Hunninghake GW. Respiratory epithelial cells convert 
inactive vitamin D to its active form: potential effects on host defense. J Immunol. 2008; 181:7090-9.

42. Nakagawa K, Kawaura A, Kato S, Takeda E, Okano T. $1 \alpha, 25$-Dihydroxyvitamin D 3 is a preventive factor in the metastasis of lung cancer. Carcinogenesis. 2005; 26:429-40. doi: 10.1093/carcin/bgh332.

43. Nakagawa K, Sasaki Y, Kato S, Kubodera N, Okano T. 22-Oxa-1alpha,25-dihydroxyvitamin D3 inhibits metastasis and angiogenesis in lung cancer. Carcinogenesis. 2005; 26:1044-54. doi: 10.1093/carcin/bgi049.

44. Simboli-Campbell M, Narvaez CJ, Tenniswood M, Welsh J. 1,25-Dihydroxyvitamin D3 induces morphological and biochemical markers of apoptosis in MCF-7 breast cancer cells. J Steroid Biochem Mol Biol. 1996; 58:367-76.

45. Herbst RS, Heymach JV, Lippman SM. Lung cancer. N Engl J Med. 2008; 359:1367-80. doi: 10.1056/NEJMra0802714.

46. Hershberger PA, Modzelewski RA, Shurin ZR, Rueger RM, Trump DL, Johnson CS. 1,25-Dihydroxycholecalciferol $(1,25-\mathrm{D} 3)$ inhibits the growth of squamous cell carcinoma and down-modulates $\mathrm{p} 21$ (Waf1/Cip1) in vitro and in vivo. Cancer Res. 1999; 59:2644-9.

47. Zhou W, Suk R, Liu G, Park S, Neuberg DS, Wain JC, Lynch TJ, Giovannucci E, Christiani DC. Vitamin D is associated with improved survival in early-stage non-small cell lung cancer patients. Cancer Epidemiol Biomarkers Prev. 2005; 14:2303-9. doi: 10.1158/1055-9965.epi-05-0335.

48. Krishnan AV, Swami S, Peng L, Wang J, Moreno J, Feldman D. Tissue-selective regulation of aromatase expression by calcitriol: implications for breast cancer therapy. Endocrinology. 2010; 151:32-42. doi: 10.1210/ en.2009-0855.

49. Lee G, Walser TC, Dubinett SM. Chronic inflammation, chronic obstructive pulmonary disease, and lung cancer. Curr Opin Pulm Med. 2009; 15:303-7. doi: 10.1097/ MCP.0b013e32832c975a.

50. Young RP, Hopkins RJ. Link between COPD and lung cancer. Respir Med. 2010; 104:758-9. doi: 10.1016/j. rmed.2009.11.025.

51. Skaaby T, Husemoen LL, Thuesen BH, Pisinger C, Jorgensen T, Fenger RV, Linneberg A. Vitamin D status and chronic obstructive pulmonary disease: a prospective general population study. PLoS One. 2014; 9: e90654. doi: 10.1371/journal.pone.0090654.

52. Morabia A, Bernstein MS, Antonini S. Smoking, dietary calcium and vitamin D deficiency in women: a populationbased study. Eur J Clin Nutr. 2000; 54:684-9.

53. Subar AF, Harlan LC, Mattson ME. Food and nutrient intake differences between smokers and non-smokers in the US. Am J Public Health. 1990; 80:1323-9.

54. Brot C, Jorgensen NR, Sorensen OH. The influence of smoking on vitamin D status and calcium metabolism. Eur J Clin Nutr. 1999; 53:920-6.

55. Jorde R, Saleh F, Figenschau Y, Kamycheva E, Haug E, Sundsfjord J. Serum parathyroid hormone (PTH) levels in smokers and non-smokers. The fifth Tromso study. Eur J Endocrinol. 2005; 152:39-45.

56. Skaaby T, Husemoen LLN, Thuesen BH, Pisinger C, Hannemann A, Jørgensen T, Linneberg A. Longitudinal associations between lifestyle and vitamin D: A general population study with repeated vitamin D measurements. Endocrine. 2015; 51:342-50. doi: 10.1007/s12020-0150641-7.

57. Matsunawa M, Amano Y, Endo K, Uno S, Sakaki T, Yamada S, Makishima M. The aryl hydrocarbon receptor activator benzo[a]pyrene enhances vitamin D3 catabolism in macrophages. Toxicol Sci. 2009; 109:50-8. doi: 10.1093/ toxsci/kfp044.

58. Bolton-Smith C, Woodward M, Brown CA, TunstallPedoe H. Nutrient intake by duration of ex-smoking in the Scottish Heart Health Study. Br J Nutr. 1993; 69:315-32.

59. Need AG, Kemp A, Giles N, Morris HA, Horowitz M, Nordin BE. Relationships between intestinal calcium absorption, serum vitamin D metabolites and smoking in postmenopausal women. Osteoporos Int. 2002; 13:83-8. doi: 10.1007/s198-002-8342-9.

60. Li H, Stampfer MJ, Hollis JB, Mucci LA, Gaziano JM, Hunter D, Giovannucci EL, Ma J. A prospective study of plasma vitamin D metabolites, vitamin D receptor polymorphisms, and prostate cancer. PLoS Med. 2007; 4: e103. doi: 10.1371/journal.pmed.0040103.

61. Zhou W, Heist RS, Liu G, Asomaning K, Neuberg DS, Hollis BW, Wain JC, Lynch TJ, Giovannucci E, Su L, Christiani DC. Circulating 25-hydroxyvitamin D levels predict survival in early-stage non-small-cell lung cancer patients. J Clin Oncol. 2007; 25:479-85. doi: 10.1200/ JCO.2006.07.5358.

62. Bouillon R, Eelen G, Verlinden L, Mathieu C, Carmeliet G, Verstuyf A. Vitamin D and cancer. J Steroid Biochem Mol Biol. 2006; 102:156-62. doi: 10.1016/j.jsbmb.2006.09.014.

63. Higashimoto $\mathrm{Y}$, Ohata $\mathrm{M}$, Nishio $\mathrm{K}$, Iwamoto $\mathrm{Y}$, Fujimoto H, Uetani K, Suruda T, Nakamura Y, Funasako M, Saijo N. 1 alpha, 25-dihydroxyvitamin D3 and all-transretinoic acid inhibit the growth of a lung cancer cell line. Anticancer Res. 1996; 16:2653-9.

64. Egan KM, Signorello LB, Munro HM, Hargreaves MK, Hollis BW, Blot WJ. Vitamin D insufficiency among African-Americans in the southeastern United States: implications for cancer disparities (United States). Cancer Causes Control. 2008; 19:527-35. doi: 10.1007/s10552008-9115-z.

65. Ashwell M, Stone EM, Stolte H, Cashman KD, Macdonald H, Lanham-New S, Hiom S, Webb A, Fraser D. UK Food Standards Agency Workshop Report: an investigation of the relative contributions of diet and sunlight to vitamin D status. Br J Nutr. 2010; 104:603-11. doi: 10.1017/S0007114510002138.

66. Arantes HP, Kulak CA, Fernandes CE, Zerbini C, Bandeira F, Barbosa IC, Brenol JC, Russo LA, Borba VC, 
Chiang AY, Bilezikian JP, Lazaretti-Castro M. Correlation between 25-hydroxyvitamin D levels and latitude in Brazilian postmenopausal women: from the Arzoxifene Generations Trial. Osteoporos Int. 2013; 24:2707-12. doi: 10.1007/s00198-013-2366-x.

67. Wells GA, Shea B, O'Connell D, Peterson J, Welch V, Losos M, Tugwell P. he Newcastle - Scale for assessing the quality of nonrandomised studies in meta-analyses. Ottawa Health Research Institute Web site. 2014.

68. Moher D, Liberati A, Tetzlaff J, Altman DG. Preferred reporting items for systematic reviews and meta-analyses: the PRISMA statement. PLoS Med. 2009; 6: e1000097. doi: 10.1371/journal.pmed.1000097.

69. Symons MJ, Moore DT. Hazard rate ratio and prospective epidemiological studies. J Clin Epidemiol. 2002; 55:893-9.

70. Zgaga L, O’Sullivan F, Cantwell MM, Murray LJ, Thota PN, Coleman HG. Markers of Vitamin D Exposure and Esophageal Cancer Risk: A Systematic Review and Meta-analysis. Cancer Epidemiol Biomarkers Prev. 2016; 25:877-86. doi: 10.1158/1055-9965.EPI-15-1162.

71. Greenland S. Quantitative methods in the review of epidemiologic literature. Epidemiol Rev. 1987; 9:1-30.

72. Greenland S, Longnecker MP. Methods for trend estimation from summarized dose-response data, with applications to meta-analysis. Am J Epidemiol. 1992; 135:1301-9.

73. Orsini N, Bellocco R, Greenland S. Generalized least squares for trend estimation of summarized dose-response data. Stata Journal. 2006; 6:40-57.

74. Afzal S, Bojesen SE, Nordestgaard BG. Low plasma 25-hydroxyvitamin D and risk of tobacco-related cancer. Clin Chem. 2013; 59:771-80. doi: 10.1373/clinchem.2012.201939.

75. Wang X, Cui J, Gu J, He H, Li B, Li W. Plasma 25-hydroxyvitamin D deficiency is associated with the risk of non-small cell lung cancer in a Chinese population. Cancer Biomark. 2015; 15:663-8. doi: 10.3233/CBM-150506.

76. Wong YY, Hyde Z, McCaul KA, Yeap BB, Golledge J, Hankey GJ, Flicker L. In older men, lower plasma 25-hydroxyvitamin $\mathrm{D}$ is associated with reduced incidence of prostate, but not colorectal or lung cancer. PLoS One. 2014; 9: e99954. doi: 10.1371/journal.pone.0099954.

77. Vashi PG, Edwin P, Popiel B, Gupta D. The relationship between circulating 25-hydroxyvitamin $\mathrm{D}$ and survival in newly diagnosed advanced non-small-cell lung cancer. BMC Cancer. 2015; 15: 1012. doi: 10.1186/s12885-015-2043-x.

78. DerSimonian R, Laird N. Meta-analysis in clinical trials. Control Clin Trials. 1986; 7:177-88.

79. Cochran WG. The combination of estimates from different experiments. Biometrics. 1954; 10:101-29.

80. Higgins JP, Thompson SG, Deeks JJ, Altman DG. Measuring inconsistency in meta-analyses. Bmj. 2003; 327:557-60. doi: 10.1136/bmj.327.7414.557.
81. Egger M, Davey Smith G, Schneider M, Minder C. Bias in meta-analysis detected by a simple, graphical test. Bmj. 1997; 315:629-34.

82. Kilkkinen A, Knekt P, Heliovaara M, Rissanen $\mathrm{H}$, Marniemi J, Hakulinen T, Aromaa A. Vitamin D status and the risk of lung cancer: a cohort study in Finland. Cancer Epidemiol Biomarkers Prev. 2008; 17:3274-8. doi: 10.1158/1055-9965.EPI-08-0199.

83. Weinstein SJ, Yu K, Horst RL, Parisi D, Virtamo J, Albanes D. Serum 25-hydroxyvitamin D and risk of lung cancer in male smokers: a nested case-control study. PLoS One. 2011; 6: e20796. doi: 10.1371/journal.pone.0020796.

84. Cheng TY, Lacroix AZ, Beresford SA, Goodman GE, Thornquist MD, Zheng Y, Chlebowski RT, Ho GY, Neuhouser ML. Vitamin D intake and lung cancer risk in the Women's Health Initiative. Am J Clin Nutr. 2013; 98:1002-11. doi: 10.3945/ajcn.112.055905.

85. Cheng TY, Goodman GE, Thornquist MD, Barnett MJ, Beresford SA, LaCroix AZ, Zheng Y, Neuhouser ML. Estimated intake of vitamin D and its interaction with vitamin A on lung cancer risk among smokers. Int J Cancer. 2014; 135:2135-45. doi: 10.1002/ijc.28846.

86. Redaniel MT, Gardner MP, Martin RM, Jeffreys M. The association of vitamin D supplementation with the risk of cancer in postmenopausal women. Cancer Causes Control. 2014; 25:267-71. doi: 10.1007/s10552-013-0328-4.

87. Mahabir S, Forman MR, Dong YQ, Park Y, Hollenbeck A, Schatzkin A. Mineral intake and lung cancer risk in the NIH-American Association of Retired Persons Diet and Health study. Cancer Epidemiol Biomarkers Prev. 2010; 19:1976-83. doi: 10.1158/1055-9965.EPI-10-0067.

88. Li K, Kaaks R, Linseisen J, Rohrmann S. Dietary calcium and magnesium intake in relation to cancer incidence and mortality in a German prospective cohort (EPICHeidelberg). Cancer Causes Control. 2011; 22:1375-82. doi: 10.1007/s10552-011-9810-z.

89. Liu Y, Chen W, Hu ZB, Xu L, Shu YQ, Pan SY, Dai JC, Jin GF, Ma HX, Shen HB. Plasma Vitamin D Levels And Vitamin D Receptor Polymorphisms Are Associated with Survival of Non-small Cell Lung Cancer. Chin J Cancer Res. 2011; 23:33-7. doi: 10.1007/s11670-011-0033-3.

90. Tretli S, Schwartz GG, Torjesen PA, Robsahm TE. Serum levels of 25-hydroxyvitamin D and survival in Norwegian patients with cancer of breast, colon, lung, and lymphoma: a population-based study. Cancer Causes Control. 2012; 23:363-70. doi: 10.1007/s10552-011-9885-6. 